\title{
Factors Predicting Travelers' Satisfaction of Three to Five Star Hotels in Asia, an Online Review
}

\author{
${ }^{1}$ Fatemeh Khozaei, ${ }^{2}$ Golnaz Nazem, ${ }^{3}$ T Ramayah, ${ }^{4}$ Sivabala Naidu \\ ${ }^{1}$ Department of Art Architecture, Kerman Branch, Islamic Azad University, Kerman, Iran \\ ${ }^{2}$ School of Housing, Building and Planning, Universiti Sains Malaysia, Penang, Malaysia \\ ${ }^{3}$ School of Management, Universiti Sains Malaysia, Minde, 11800 Penang, Malaysia \\ ${ }^{4}$ School of Education, Faculty of Arts and Social Science, University of Nottingham \\ ${ }^{1}$ Fkhozaei2013@gmail.com, ${ }^{2}$ missgoli@ymail.com, ${ }^{3}$ ramayah@usm.my, ${ }^{4}$ sivabala27@gmail.com
}

\begin{abstract}
Despite the great number of tourists that attracted each year, there are only a limited number of studies that have looked at customers' satisfaction of hotels in the Asian region. This study, hence, is an attempt to fill a part of this gap. The study examines factors that affect the satisfaction of hotel guests of 1800 hotels in 40 Asian countries based on their online reviews. The data analysis was conducted via both text mining and content analysis of the online reviews posted by reviewers from one particular website - Agoda.com. The content analysis was conducted with the aid of Nvivo 7. This study observes that staff, value, location, food and dining area as well as room and hotel physical attributes are main factors that affect the customers' satisfaction within three to five star hotels. It was further found that mismatches between travelers' initial expectations compared with their actual experience such as online hotel images versus their real conditions, facilities or amenities promised but not received or of poor quality service were major causes of travelers' dissatisfaction. The current study is one of very few studies that canonize customers' satisfaction of three to five star hotels in Asia based on a large number of reviews available online.
\end{abstract}

Keywords: Online review, customer satisfaction, hotel ranking, text mining, content analysis, Asia

\section{INTRODUCTION}

Online hotel reservation websites have become very popular among travelers in recent years as there is a great deal of information on the various facets of hotels services readily available. For instance, prospective travelers can conveniently search for the availability of rooms on specific days, the facilities offered at different hotels and their price-ranges. With such information, it is generally expected that customers are able to make informed bookings based on their preferences in terms of hotel ratings and budget. In addition, they can also compare various hotel ratings based on the travelers' scores on each hotel and read the reviews of previous guests. Basic background information of the reviewers such as the types of travelers (e.g. solo travelers, business travelers, family with the young children, family with the older children, or couples etc.), years of travel and the travelers' nationalities are also easily obtained from the reviews. In addition, the online reviews also provide their comments and feedback on the hotels that they had stayed in during their visit to a particular destination. Previous studies suggest that "tourist knowledge positively influences customization and customization affects satisfaction" (Lee, Lin, Lee, Yeh \& Lee, 2015).

A repeated negative element in the reviews such as complaints about the staff can sway a prospective hotel guest's decision. This is because the information provided is generally accepted to be reliable as it is based real-life experiences of the reviewers. Additionally, these websites also provide valuable information about the perception of customers on the hotel facilities, staff performance and related aspects to the hotels' management.

Online reviews' value in advancing information about customers' expectations, satisfaction and dissatisfaction has led to a growing number of research in this area in the past few years $(\mathrm{Li}, \mathrm{Ye}, \&$ Law, 2013; Zhou, Ye, Pearce \& Wu 2014; Darini \& Khozaei 2016).

This study places its critical lens on hotels in Asian countries as they attract a large number of tourists from around the world due to their lower rates. Popularity of Asian tourist destinations offers a wide variety of attractions including but not limited to, historical sites. Asian travel destinations attract 
travelers from a large number of countries who tend to express different expectations of hotel services which, in turn, have an effect on their overall satisfaction levels. A cursory survey of related studies indicates that very few studies are exclusively related to online hotel reviews in Asia (Zhou et al. 2014; Darini \& Khozaei 2016). These few studies have also focused on just a few cities, and hence, our knowledge on factors that affect the customers' satisfaction with their accommodation in Asian countries is very limited.

This study hopes to fill a part of this gap and add to the body of knowledge pertaining to factors that has affected hotel guests' perception and ratings of hotel in 40 Asian countries based on the availability of reviews in Agoda.com. This study's focus on particular areas related to the hotel industry is grounded on the findings of past studies focusing on the factors that have influenced guest satisfaction levels.

In relation to this, the study of Zhou et al. (2014) mentions factors and attributes that had affected customers' satisfaction regarding four and five star hotels in Hangzhou, China. They pose 23 attributes under 6 main categories influence customer satisfaction. As presented in table 1, the main categories are physical settings of the rooms, the hotel itself, food, overall value, location and staff.

Table1. Factors that Contribute to Four and Five Star Hotel Satisfaction in Hangzhou, China. (Zhou Et Al. 2014)

Twenty-three attributes that influence hotel customer satisfaction.

\begin{tabular}{ll}
\hline Attribute category & Detailed attributes \\
\hline Physical setting - room & $\begin{array}{l}\text { Amenities in the room/bathroom; size and } \\
\text { layout of the room; cleanliness of the room; } \\
\text { welcoming extras }\end{array}$ \\
Physical setting - hotel & $\begin{array}{l}\text { Availability of Wifi; public facilities (lounge, } \\
\text { lobby, pool and fitting centre); dated level } \\
\text { (old/new); noise level; entertainment facilities }\end{array}$ \\
& A variety of food (including western food); the \\
Physical setting - food & quality of food; the dining environment; \\
& availability of special food service (room \\
& service; vegetarian and gluten free options) \\
& Room price; food and beverage price, and \\
other prices & Close to attractions; close to city centre; close \\
Value & to the airport/railway station; and accessibility \\
Location & Friendliness of the staff; language skills of the \\
Staff & staff; efficiency of the staff in solving problems
\end{tabular}

This study attempts to examine contributing factors of customers' satisfaction on three, four and five star hotels in Asian countries. The focus will be on a pool of items that can be extended in the future.

\section{REVIEW OF THE LITERATURE}

\subsection{Customer Satisfaction with Hotels}

There are a wide range of studies that have investigated factors influencing hotel guests' satisfaction (Bulchand-Gidumal, 2013; Li et al., 2013) which postulate that satisfaction with a service or product enhances the chance of hotel guests' intention to return in the future. Several other studies indicate that "staff service and room quality and overall value are the three most influential factors in determining travelers' overall satisfaction levels. This, in turn, affects their likelihood of returning to the same hotels" in the future (Choi and Chu, 2001, p. 277). However, as Shanahan and Hyman (2006) examine the most desirable hotel attributes of American tourists argue; the degree of satisfaction that guests have for hotels which offer equivalent service can greatly differ between hotels in developed and developing countries.

On the whole, it has been noted that the service provided by hotel employees greatly influence the rating provided by the guests. For instance, Kattara, Weheba and Ahmed El-Said (2014, 225) claim that "employees' behaviors have a great effect on overall customer satisfaction regardless of customers' gender, nationality, and purpose of visit, number of visits and their length of stay." Similarly, studies also support the notion that helpfulness of staff manning the information desk (Heung 2000) providing accurate and rapid professional service (Lin, Tsai, Wang, Su \& Shaw 2011) 
can positively affect customer satisfaction. Past studies also indicate that room quietness, the availability of in-room safety boxes, hygiene and cleanliness of the premises, availability of personal care (Heung, 2000), safety and external leisure environments (Lin et al. 2011) also affect customer satisfaction. Other factors that have been established as important in influencing customer satisfaction are "tangible, sensorial experience, staff aspect, aesthetic perception, and location" (Ren et al., 2016).

\subsection{Studies Based on Hotel Online Reviews}

Online reviews by customers of various businesses and services in social groups and other online platforms have become an important part of the social structure and wield significant power over customer choice (Park, 2002). Such reviews make it possible for researchers to have access to large amounts of data. Related work by Bulchand-Gidumal (2013) argues that the social media has an influence on consumers' decisions on particular businesses and services such as, decisions on hotel selection (Stringam et al. 2010). Negative experiences encountered by customers on any one aspect of the hotel can affect their overall perception and subsequently lower the rating of the hotel (Stringam et al., 2010).

Li et al. (2013) supplied a content analysis of online reviews of 774 hotels available at the daodao.com website. The site notes six main factors which influenced customer satisfaction:

i. Logistics (e.g., transportation, accessibility to tourist destinations, etc.)

ii. Facilities (room, air conditioning, internet connection, sound insulation, etc.)

iii. Reception services (luggage management, check in/out service, morning call, etc.,)

iv. Food and beverage management (breakfast, lunch, dinner, room service)

v. Cleanliness and maintenance (room cleaning, bathroom, bedding, etc.)

vi. Perception of value for money

Similarly, Rhee and Yang (2013) who analyzed 405 reviews posted on TripAdvisor.com. This shows that 'value for money' and 'rooms' are considered as the most important attributes that contribute to a high overall rating for hotels. A more recent study by Darini and Khozaei (2016) argues that hotel location, food management, cleanliness, facilities, design and staff behaviour are main influencing factors that affect customer satisfaction denoting three-star hotels in Dubai.

\subsection{Hotel Selection Factors}

The determinant attributes of travelers' choices of hotel selection as well as their feedback have been high contributions to a wide variety of research contexts (Lin et al., 2011; Huertas-Garcia et al., 2012). Other elated literature suggests that 'value for money', 'cleanliness', 'comfort of beds', 'politeness of staff', 'efficiency of service' and 'location' affect the hotel selection (Callan \& Bowman, 2000). Chu and Choi (2000) write that business and leisure travelers have similar preferences which may affect their decision on hotel choices. For business travelers, room and front desk service are considered as important while leisure travelers choose 'security' as the most important factor. However, no other significant difference was found in the choices of these two groups. Kumar and Singh's study (2014) found that Indian tourists considered 'aesthetic sense in the hotel public areas and rooms' as important alongside the usual factors such as 'value for money' and 'cleanliness'.

The works of Chan and Wong (2006) write that "beyond room rates (pricing), convenient hotel location and good service were the key factors influencing travelers in their final hotel selection. Business travelers tend to place more emphasis on their previous hotel experience; good service; convenience and company recommendation, whereas, leisure travelers and those with a lower level of education value travel agent recommendation. Agag and El-Masry $(2016,52)$ point out that staff commitment, trust and attitude have a high influence on customers' intention to make online hotel bookings.

\section{RESEARCH METHODOLOGY}

Grounded on the findings of previous research (Zhou et al., 2014)., the main aim of the current study is to examine the factors that affect customer satisfaction in three, four and five star hotels in 40 countries in Asia In the same way, current research utilises text mining and content analysis of traveler reviews from the Agoda website to achieve its objectives. This site only publishes reviews from travelers who have booked and paid for reservations through their websites. This would indicate that the reviews are by bona fide guests. The reviews are structured and travelers are basically 
required to provide overall satisfaction ratings for the hotels based on their evaluation of their experience during their stay. The website also provides databases of individual customer reviews consisting of customer evaluations based on their experiences of hotels worldwide.

The online reviews utilised in this study were categorized under the Asian category in Agoda.com. Consequently, all 40 countries were included in the research. As Zhou et al (2014) looks at factors and attributes of customer satisfaction of 4 and 5 star hotels, the initial focus of this study is merely on the reviews of three star hotels. This was aimed at comparing whether the customers of this hotel category have similar or different opinions. Using the website's search tool filtering system, the researchers extracted reviews of the first fifteen hotels were generated by the agoda.com website.

After the initial steps of extracting the reviews, they were transferred into a single manageable word document and exported into the Nvivo 7 qualitative data analysis software. The reviews were analysed applying content analysis, allowing the researchers to make inferences from the text about implied meanings of data (Krippendorff, 2012). The researchers opted for this methodology as it provided a framework for a systematic reading of the written reviews.

The 6 factors contributing to hotel customers' satisfaction namely, staff, location, value, physical hotel setting, physical room and food setting were taken as a guide to read the comments by the reviewers. Intricate readings of the texts involved coding of categories - each sentence is read multiple times by each of the researchers independently and categorised based on the relevant hotel attributes that were implied. The categorisations were then cross-checked for consistency of categorisation between the researchers. Where differences appeared, the researchers discussed the categorisation to arrive at a unanimous decision. Once the content analsysis of the first set of reviews (three-star hotels) was completed, the steps were reiterated to fit into the four and five star hote reviews. In total 1800 number of hotels were studied as seen below.

\section{Data Analysis AND Findings}

\subsection{Unmet Expectations and Dissatisfaction}

One of the main sources of information for potential guest decision making on hotel choice is previous comments as gleaned from the following statement:

Their experience:

a. "We booked 3 standard rooms for one night with my friends at the last minute via Agoda as $\underline{\boldsymbol{w} e}$ saw good reviews from other travelers and the rate was reasonable."

This recognizes the important role of hotel reviews on other travelers' decisions. More importantly, any mismatching between customer expectations and reality could easily result in dissatisfaction as observed in the analysis of the comments. The majority of the reviews that were negative were mainly due to discrepancies between customers' actual experiences and their prior expectations. The expectations are largely shaped by the information that had been gathered from hotel websites, for example, from the images of the rooms and facilities. In other words, customers were naturally piqued when the advertised material such as images provided them with positive expectations that did not match with the actual situation. This is noted in the following assertions:

a. The pictures on the website do not give a true impression of the place.

b. Nothing, it was the horrible hotel that I have ever stayed in my life. The pictures on booking were nice but reality was not good. I hate that hotel.

Other comments indicated that customers tended to expect that whatever is 'promised' in terms of services and facilities will be obtained without difficulties. If such expectations are not met, for instance, if the facilities aren't working properly or are not available, dissatisfaction with the hotel sets in:

a. The air-conditioning didn't cool our room at all. The fridge wasn't working

$b$. The telephone wasn't working, the TV was not working, so we will not revisit or recommend this hotel to anyone

c. I've stayed 2 days without internet; they said they have a problem even though it was included in the rate... 
d. I didn't get pick up from the airport even though I indicated this in my online booking

e. The hotel claims to have a parking space, but in reality they would ask you to park in a truck parking yard in front of the hotel.

On the other hand, customers' expectations showed a notable decrease when the hotel rates are considered affordable and tend to display more tolerance and acceptance of the facilities.

a. The breakfast might not be of 5 star quality however the varieties are quite satisfying.

b. The gym is small but that's not why you are there.

c. I just needed a bed to sleep in and the hotel suited my need.

d. I don't expect anything special but good for budget travelers.

e. Rooms are not very clean but it is a good choice for someone who is on budget.

f. Remember that this is one of the cheapest hotels in Bahrain so don't expect the extravagance of some of the upscale hotels in the area.

In contrast, when the reality exceeded travelers' initial expectations, they were very pleased. For example, a customer who had his room upgraded at no charge was delighted with the upgrade:

a. It was the best! Was upgraded to their executive suite (biggest room) for free!!! For no reason. Hahahaha it was fantastic!!!

One of the findings of this study indicates that customers tend to generalize an act or behaviour of an employee as an indicator of their personality as the following examples show:

a. The front office staff was rude and unsympathetic.

b. He never smiled and he was not helpful at all.

The construction of the sentence signposts an important customer linguistic behaviour - the reviewer did not write "he didn't behave politely" or "he behaved rudely" in reference to a specific incident; instead he/she made a conclusion that the receptionist was rude and unsympathetic in general. In conclusion, a customers' perception of an employee might come from a mere visit and a second opportunity which might not exist to compensate any wrong behaviour. An unmet expectation also can affect the customers' whole experience with the hotel thus creating dissatisfaction which can lead to a decision not to return to that particular hotel in the future. There will be a likelihood of not recommending this hotel to anyone as indicated in the comment below:

a. Disgusting!! I booked for standard room expecting there are 2 beds, to my dismay the staff said there is no available so she gave us to 1 bed room!! I will never recommend ...... hotel to anyone!!!

\subsection{Factors Predicating Customers' Satisfaction}

\subsubsection{Staff}

Reviews on hotels are a great source of information on both the positive and negative behaviours of employees. It also sheds light on the behaviours that are appreciated or reported as unpleasing by hotel guests. In describing the negative behaviours of hotel employees, reviewers labeled them as "rude", "unsympathetic", "impolite", "unhelpful", "slow", "unwelcoming" while positive attributes were noted as "polite", "helpful", "responsive", "friendly", and "attentive".

Zhou et al. (2014) indicates 3 attributes about the quality of the staff; their language skills and their efficiency in solving problems as factors that affect customer satisfaction. Similarly, the reviews that were analysed had indicated certain attributes that considered relevant to Zhou et al. (2014) categorized as staff behavior and mannerism (friendliness of staff, being patient and kind, politeness, honesty, equal treating of customers).

In table 2 below, staff behaviour and associated attributes are listed:

Table2. Staff Behaviour and Attributes

\begin{tabular}{ll}
\hline Staff manner and behaviour & \\
\hline *Friendliness of staffs & \\
\hline $\begin{array}{l}\text { Once arrived in the hotel we were nicely greeted } \\
\text { "every day I felt welcomed like it was my first day" }\end{array}$ & $\begin{array}{l}\text { *Warm greeting upon arrival } \\
\text { *Repeated warm greetings and } \\
\text { behaviour everyday } \\
\text { *Friendly advices about the city } \\
\text { **not smiling } \\
\text { First thing the staffs did was the dos and don'ts whilst in Istanbul.. } \\
\text {... do not smile and exude warm or hospitality } \\
\text { "he also gave some tips on where to shop" }\end{array}$ \\
\begin{tabular}{ll} 
Friendly staff organized us a cheap trip to Petra & *Arranging a cheap trip \\
\hline *Being patient and kind &
\end{tabular} \\
\hline International Journal of Research in Tourism and Hospitality (IJRTH)
\end{tabular}


Fatemeh Khozaei et al.

\begin{tabular}{|c|c|}
\hline Hotel desk staff answered all my 100 questions & $\begin{array}{l}\text { *Being patient with the customers' } \\
\text { questions }\end{array}$ \\
\hline $\begin{array}{l}\text { "I over slept up to } 13: 30 \text { and the staff were nice (no one talked to me } \\
\text { about the late check out)" }\end{array}$ & $\begin{array}{l}\text { *Being patient with the guests late } \\
\text { check out }\end{array}$ \\
\hline $\begin{array}{l}\text { "even though we arrived early at } 9 \mathrm{Am} \text {, before check in time, they } \\
\text { invited us to have the breakfast" }\end{array}$ & *In breakfast before check in time \\
\hline "The kitchen was closed already, but they opened it up just for us " & $\begin{array}{l}\text { *Opening kitchen in un promised } \\
\text { hours }\end{array}$ \\
\hline $\begin{array}{l}\text { "The staff at reception spontaneously offered to lend me their pre- } \\
\text { charged metro pass instead of having to buy more expensive single } \\
\text { travel tickets!" }\end{array}$ & $\begin{array}{l}\text { *lending their personal metro card } \\
\text { to the customer }\end{array}$ \\
\hline "... gave us Wi-Fi access even if we check out already" & $\begin{array}{l}\text { *Giving access to Wi-Fi after } \\
\text { check out }\end{array}$ \\
\hline "the receptionist who let us check out late" & $\begin{array}{l}\text { *allowing customer to check out } \\
\text { late }\end{array}$ \\
\hline \multicolumn{2}{|l|}{ Politeness } \\
\hline "The staff are polite" & *staff politeness \\
\hline \multicolumn{2}{|l|}{ Equal treating of customers } \\
\hline "Some customers were assisted with their luggag & $\begin{array}{l}* * \text { Unequal action in having their } \\
\text { luggage attended }\end{array}$ \\
\hline \multicolumn{2}{|l|}{ Honesty } \\
\hline $\begin{array}{l}\text { The room service staff cheating for my money change! Every time he } \\
\text { gave me a less change. }\end{array}$ & $\begin{array}{l}\text { *honesty in changing money for } \\
\text { customers }\end{array}$ \\
\hline \multicolumn{2}{|l|}{ Language skills } \\
\hline "the staff ... have good command of English language" & *good command in English \\
\hline \multicolumn{2}{|l|}{ Efficiency in solving problems } \\
\hline $\begin{array}{l}\text { "I didn't have to stand more than } 10 \text { seconds in the queue that the hotel } \\
\text { invited me to sit down and relax and within } 2 \text { minutes another staff } \\
\text { member had opened another check-in desk to attend to me" }\end{array}$ & *Fast check in \\
\hline Staff was friendly and they quickly respond to our requests. & $\begin{array}{l}\text { *Quick response to the guests' } \\
\text { inquiries }\end{array}$ \\
\hline $\begin{array}{l}\text { "credit goes to the housekeeping whom is so considerate and given best } \\
\text { services" }\end{array}$ & *good house keeping \\
\hline "housekeeping do not clean the room if I didn't call" & $\begin{array}{l}\text { **lack of responsibility for daily } \\
\text { house keeping }\end{array}$ \\
\hline $\begin{array}{l}\text { "...the fourth day room service came at } 19.00 \text { when we were in the } \\
\text { room, the fifth day they came at } 9.00 \text { in the morning when we were still } \\
\text { asleep" }\end{array}$ & $* *$ Irregular timing for services \\
\hline "to remind them each 15 mins or you will never get anything" & $* *$ Requiring several reminder \\
\hline "we stayed 4 days they never fill the tea bag or coffee" & $* *$ Not filling the coffee bags \\
\hline Breakfast starts at 7 but nothing was ready at time & $\begin{array}{l}* * \text { no on time preparation of } \\
\text { breakfast }\end{array}$ \\
\hline
\end{tabular}

*Satisfactory Behaviour, **Dissatisfactory Behaviour

\subsection{Location}

Hotel location was identified as one of the most influential factors that had affected reviewer satisfaction. The proximity of the hotel to destinations is normally measured against time taken to get to the spots on foot. For instance, the reviewers stated "few minutes walking distance from..." "15 to 30 minutes from..." and "right near..." to describe the location of the hotel favorably. On the whole, when the hotel is located less than 30 minutes away to the identified destinations, the hotel's location is rated as satisfactory.

In describing the positive attributes of a hotel location that cause customer satisfaction Zhou et al. (2014) indicates the following observations: being "close to attractions, close to city centre, close to airport/railway station and accessibility" as positive for the hotels. In addition, close proximity to 
restaurants and the quality of surrounding space was also found to affect customer satisfaction (see table 3).

Table3. Attributes Associated with Location

\begin{tabular}{|c|c|}
\hline \multicolumn{2}{|l|}{ Close to attractions and facilities } \\
\hline All the major attractions are about 15 to 30 min away from the hotel. & $\begin{array}{l}\text { *Near to city all major } \\
\text { attractions }\end{array}$ \\
\hline Few minutes walking distance to the historical sites. & *near historical sites \\
\hline $\begin{array}{l}\text { "the location of the hotel is perfect at the heart of Bahrain and is accessible to } \\
\text { all like the church, shopping areas and restaurants" }\end{array}$ & *near Church \\
\hline Near Mall of the Emirates, & *near city landmarks \\
\hline The hotel was situated beside a supermarket and dozens of restaurants & *Near to restaurant \\
\hline \multicolumn{2}{|l|}{ Close to city centre } \\
\hline Location of hotel is good in the center of the city & $*$ close to city center \\
\hline \multicolumn{2}{|l|}{ Close to airport / railway station } \\
\hline 10-minute drive from the airport and close to the city's main commercial, & *close to the airport \\
\hline \multicolumn{2}{|l|}{ Accessibility } \\
\hline $\begin{array}{l}\text { Good location, right near the subway." } \\
\text { The location is a little isolated but there is a metro station right outside. } \\
\text { Situated up a very steep road so not really suitable for elder folks. }\end{array}$ & $\begin{array}{ll}* \text { Near } & \text { public } \\
\text { transportation } & \text { (metro } \\
\text { station, } & \\
* * \text { Situated up hill } & \end{array}$ \\
\hline \multicolumn{2}{|l|}{ Quality of surrounding environment } \\
\hline The view was amazing overlooking the valley. & *Beautiful surrounding \\
\hline \multicolumn{2}{|l|}{ The location is great and the view of the sea and garden was relaxing } \\
\hline $\begin{array}{l}\text { It is located a little away from Petra town so very quiet and so good for } \\
\text { relaxing }\end{array}$ & *Quiet and relaxing \\
\hline $\begin{array}{l}\text { To sleep in that room was like sleeping next to the freeway. Cars and trucks } \\
\text { are noisy until early morning. }\end{array}$ & $\begin{array}{l}\text { **Noisy and crowded } \\
\text { environment }\end{array}$ \\
\hline The neighbourhood is safe as there is a police station a few blocks away. & *Secure environment \\
\hline Roads are narrow and it seems dirty all around. & $\begin{array}{l}* * \text { Not accessible } \\
\text { elderly }\end{array}$ \\
\hline
\end{tabular}

*Satisfactory **Dissatisfactory

\subsection{Physical Setting-Food}

Zhou et al. (2014) finds that availability of a wide array of food (including western food), the quality of the food, the dining environment, availability of special food service (room service, vegetarian and gluten free options) are food and related physical attributes that affect customer satisfaction. This study found that such comments were not available for the reviews of three star hotels because the guests had not expected such service from this group of hotels presumably. For the four and five star hotels, the following comments were noted (see table 4).

Table4. Attributes Associated with Physical Setting-Food

\begin{tabular}{ll}
\hline Variety of food & \\
\hline "Nothing to eat in breakfast for children & $* *$ No options for children \\
Breakfast was Ok, but the same menu everyday" & $* *$ Lack of variety in breakfast \\
"Basic breakfast and lack of variety & \\
\hline The quality of food & $* *$ stale breakfast \\
\hline "Breakfast was consistently stale (left over from previous day" & \\
\hline The dining environment & $\begin{array}{l}* * \text { noisy breakfast } \\
\text { environment }\end{array}$ \\
\hline The breakfast room is really noisy &
\end{tabular}

*Satisfactory **Dissatisfactory 


\subsection{Physical Setting-Room}

Zhou et al. (2014) also reveals the amenities in the room/ bathroom, size and layout of room, cleanliness of the rooms and welcoming extras as attributes associated with room satisfaction. The current study notes that besides room layout, customers had also pointed out some aspects related to room design and decoration. Accordingly, this attribute is categorised under "room size and design". In addition the study, finds "room quietness" as a contributing factor in customer satisfaction (see table 5).

Table5. Attributes Associated with Physical Setting-Room

\begin{tabular}{|c|c|}
\hline \multicolumn{2}{|l|}{ Facilities and Amenities in the room } \\
\hline Air-con was set by managers to heating mode and we were unable to adjust it. & $\begin{array}{l}* * \text { not adjustable air } \\
\text { temperature for customers }\end{array}$ \\
\hline The beds are hard & **uncomfortable beds \\
\hline $\begin{array}{l}\text { The sound control for the television was either zero and loud with nothing in } \\
\text { between. }\end{array}$ & **problem with the TV \\
\hline \multicolumn{2}{|l|}{ Room size and design } \\
\hline "the room was big and great" & *big room size \\
\hline The double room was so small that the door could not be opened ( 2.5 by 3.5 ). & **Small room \\
\hline Suite was very modernized. & *Modern suit \\
\hline $\begin{array}{l}\text { There seems to be a lot of unnecessary furniture in the room... and this would } \\
\text { probably be tight if travelling as a couple with lots of luggage." }\end{array}$ & **Unnecessary furniture \\
\hline The balcony in each room was added bonus. & *balcony \\
\hline The rooms aren't very sound proofed. & $\begin{array}{l}* * \text { Not sound proofed } \\
\text { rooms }\end{array}$ \\
\hline Rooms were nicely decorated with yellow colour, and was clean & *room decoration \\
\hline \multicolumn{2}{|l|}{ Cleanness of room } \\
\hline $\begin{array}{l}\text { Bathroom is very messy with bugs on the carpet. } \\
\text { The room carpet looked like it has never been cleaned. }\end{array}$ & $\begin{array}{l}* * \text { dirty bathroom } \\
* * \text { dirty carpet }\end{array}$ \\
\hline Dirty damaged noisy old furniture simply not value for money. & $* *$ dirty furniture \\
\hline $\begin{array}{l}\text { "All the curtains and bedding need to be laundered as they smelled as though } \\
\text { they haven't been washed since opening day." }\end{array}$ & **dirty curtains \\
\hline \multicolumn{2}{|l|}{ Room quietness } \\
\hline $\begin{array}{l}\text { Air condition located in balcony (no view) is so noisy makes it hard to sleep at } \\
\text { night. }\end{array}$ & **noisy room \\
\hline
\end{tabular}

*Satisfactory ** Unsatisfactory

\subsection{Physical Setting-Hotel}

Zhou et al. (2014) indicates that the physical setting of hotels includes the availability of free Wi-Fi, public facilities (lounge, lobby, pool and changing rooms), noise level and entertainment facilities. This study groups attributes associated with entertainment and public facilities, under "facilities" and removes noise level as it has been discussed on both location and room attributes. Further, the study finds hotel cleanliness, fragment and odour as contributing factors that affect customer satisfaction.

Table6. Attributes Associated with Physical Setting-Hotel

\begin{tabular}{|c|c|}
\hline Internet and Wi-Fi & \\
\hline "The only thing that disappointed us was no free Wi-Fi." & $* *$ no free $\mathrm{Wi}-\mathrm{Fi}$ \\
\hline No Wi-Fi at room but at lobby. & ** no Wi-Fi access at room \\
\hline The only cons are cable internet rather than Wi-Fi. & $* *$ cable internet access \\
\hline $\begin{array}{l}\text { Hotel internet policies are very bad. you get } 1 \text { hour free internet for the entire } \\
\text { day and that one hour is continuous and after that you have to wait for another } \\
24 \text { hours }\end{array}$ & $\begin{array}{l}* * \text { limited } \\
\text { availability }\end{array}$ \\
\hline Facilities & \\
\hline No pool side furniture & $* *$ no pool side furniture \\
\hline $\begin{array}{l}\text { We had booked this hotel primarily for use of the swimming pool. But actually } \\
\text { although the weather was very hot, the pool water was too cold to stay in more } \\
\text { than a few minutes. }\end{array}$ & $\begin{array}{l}* * \text { no proper pool water } \\
\text { temperature }\end{array}$ \\
\hline
\end{tabular}


Factors Predicting Travelers' Satisfaction of Three to Five Star Hotels in Asia, an Online Review

\begin{tabular}{|c|c|}
\hline $\begin{array}{l}\text { You have to find your own parking which could be difficult on this very busy } \\
\text { street. }\end{array}$ & **no parking access \\
\hline $\begin{array}{l}\text { Unfortunately the restaurant is so big that when there are few travelers only } \\
\text { you feel really lonely...and cold }\end{array}$ & $\begin{array}{l}* * \text { Very big and not friendly } \\
\text { restaurant }\end{array}$ \\
\hline The restaurant was beautiful and luxury seats and tables & *Luxurious seats and tables \\
\hline The view from the roof restaurant is superb." & *view from roof restaurant \\
\hline The gym had very limited opening hours. & $\begin{array}{l}* * \text { gym limited hours of } \\
\text { service }\end{array}$ \\
\hline \multicolumn{2}{|l|}{ Old or new } \\
\hline The hotel is newly renovated and the condition is good & *Renovate hotel \\
\hline \multicolumn{2}{|l|}{ Cleanliness and odor } \\
\hline The lobby was cheap and untidy. & **untidy lobby \\
\hline However the condition of the building and cleanness $i$ & $* *$ dirty building \\
\hline There is a foul smell throughout entire the hotel & $* *$ foul odor \\
\hline
\end{tabular}

\subsection{Value}

Value for money is something that is necessarily an attribute hotel guest's look forward to. As indicated by Zhou et al. (2014), this can be decided by the customer on the basis of their satisfaction with the rooms, food and beverage as well as prices of other services. In addition to these, the current study also found that customers are particularly appreciative if the hotel provides complementary services as well.

Table7. Attributes Associated with Value

\begin{tabular}{|c|c|}
\hline Room prices & \\
\hline $\begin{array}{l}\text { "I enjoyed one night at this hotel. At this price one cannot expect } \\
\text { more" }\end{array}$ & *room price \\
\hline \multicolumn{2}{|l|}{ Food and beverage price } \\
\hline \multicolumn{2}{|l|}{$\begin{array}{l}\text { Breakfast is not included and very expensive at extra cost } \\
56 \mathrm{AED} / \text { person }\end{array}$} \\
\hline \multicolumn{2}{|l|}{ Free and complementary services } \\
\hline "Free shuttle bus from hotel to shopping centres." & $* *$ free shuttle bus to shopping centers \\
\hline
\end{tabular}

\section{CONCluSion}

This study explored the factors that affect customer satisfaction of three, four and five star hotels in Asia. Through text mining and content analysis of --------- hotels from ------- countries, several interesting insights were unearthed with regard to the travelers' met and/or unmet expectations. The findings of this study are summarized and discussed below.

\subsection{Unmet Expectations and Dissatisfaction}

This study finds a mismatch between the actual quality of service and customers' expectations as a major contributing cause of dissatisfaction. The following were noted as causing dissatisfaction in the reviews that were analysed:

i. Discrepancies between the online images of hotel that are advertised and the actually state of the hotels.

ii. Discrepancies between hotel facilities (are in good working condition) and the validity of the online information on the facilities.

iii. Discrepancies between the room type or bed that is booked and what the customers actually get upon check-in.

The result of this study hence supports the findings by del Bosque and MartÃn (2008) who assert that tourists' expectations that are met will influence their level of satisfaction with the hotel they had stayed at.

\subsection{Factors Affecting Customers Satisfaction}

The study concurs with the findings of Zhou et al. (2014) which mentions that staff, location, value for money, food and dining areas, as well as physical attributes of room and hotel are all factors that affect customers' satisfaction with hotels in Asia (see table 8). The attributes that are underlined were rarely found in three star hotel reviews while the attributes that are bolded are new findings to what has already been established by Zhou and his associates. 
Fatemeh Khozaei et al.

Table8. Factors and Attributes that Affect Customers' Satisfaction

\begin{tabular}{|c|c|}
\hline Factors & Attributes \\
\hline $\begin{array}{l}\text { Physical setting- } \\
\text { room }\end{array}$ & $\begin{array}{l}\text { Facilities and Amenities in the room, Room size and design, Cleanliness of room, } \\
\text { Welcoming extras, Room quietness }\end{array}$ \\
\hline $\begin{array}{l}\text { Physical setting- } \\
\text { hotel }\end{array}$ & Internet and Wi-Fi, facilities, old or new, cleanliness and odor, entertainment facilities \\
\hline $\begin{array}{l}\text { Physical setting- } \\
\text { food }\end{array}$ & $\begin{array}{l}\text { A variety of food (including western food), the quality of food, the dining environment, } \\
\text { availability of special food service }\end{array}$ \\
\hline Value & Room price, food and beverage price, free and complementary services \\
\hline Location & $\begin{array}{l}\text { Close to attractions and facilities, Close to city centre, Close to airport / railway station, } \\
\text { Accessibility, Quality of surrounding environment }\end{array}$ \\
\hline Staff & $\begin{array}{l}\text { Staff manner and behaviour (friendliness of staff, being patient and kind, } \\
\text { politeness, equal treatment of customers, being honest), language skills of staffs, } \\
\text { efficiency in solving problems. }\end{array}$ \\
\hline
\end{tabular}

\subsubsection{Staff}

The result of this study confirms the findings of previous studies that staff can greatly influence customer satisfaction (Heung, 2000; Kattara et al., 2008; Choi \& Chu 2001). The guests' comments during their hotel stay vastly revolved around the staff's responsiveness to enquiries, their services and behaviour. Staff manner and behaviour, language skills and efficiency in solving problems were found to affect customers' satisfaction. This finding also supports Lin et al. (2011)'s findings which indicate that accurate and fast professional service by service personnel is important for customers.

A. Staff manner and behaviour Friendliness of staff (warm greetings upon arrival and repeated every day, friendly advice about the city and where to shop, pleasant and always smiling when they greet guests, helping guests secure cheap tours), Being patient and kind (Being patient with the customers' questions, being patient when guests check out later than normal check-out time, providing breakfast when guests arrive before check in time, helping to arrange for food beyond normal operating hours of the F\&B outlets, lending their personal metro card to the customer, being kind, helpful and courteous, Giving access to Wi-Fi after check out, allowing customer to check out late), Politeness, Equal treatment accorded to all customers (Equal efficiency in attending to guests' luggage), Honesty (honesty in money transactions). B. Staff language skills (The ability to speak English) C. Efficiency in solving problems (Fast check in, Quick response to the guests' inquiries, regular and efficient housekeeping services, ensuring that tea and coffee bags are replenished daily).

\subsubsection{Hotel Location}

Another important attribute repeatedly stated in the review was location of the hotel. In line with previous studies (Li et al., 2013) location and accessibility to major attractions acts as an important influencing factor to customer satisfaction. The attributes of hotel location based on customers' reviews are as follows:

A. Close to attractions (major site seeing historical sites, Churches, big shopping malls, mosques, etc.) B. Close to city centre C. Close to airport / railway station, D. Closeness to restaurant and souvenir shops E. Accessibility Near public transportation (metro station, taxi and bus stops, Accessible for elderly, F. Quality of the surrounding environment (Beautiful surroundings e.g., view of a valley, sea or garden, Quiet and relaxing, Secure environment, Clean surroundings)

\subsubsection{Physical Setting-Food}

Food plays a high role in the important factors that contribute to customers' satisfaction. The physical settings in conjunction with location and staff show that there were not as many comments in this category. The main concern in terms of food/F\&B outlets were:

A. Variety of food (Variety of food for breakfast, suitable options for children) B. The quality of food (Fresh ingredients, good quality of food) C. Dining environment (Calm and quiet environment)

\subsubsection{Physical Setting-Room}

Customers had also commented about the physical attributes of the rooms they had stayed in:

A. Facilities and Amenities in the room (Air-conditioner with adjustable temperature, comfortable bed, TV) B. Room size and design (Big room size, modernized, adequate furniture, adjacent 
balcony, sound proofed rooms) C. Cleanliness of room (Bathroom, furniture, floor and carpet, curtains) D. extras E. Room quietness

\subsubsection{Physical Setting-Hotel}

The attributes associated with customers' satisfaction with the physical attributes of hotels are listed below:

A. Internet and Wi-Fi (free Wi-Fi, room Wi-Fi coverage) B. Facilities pool [pool side furniture, proper temperature of water], parking, restaurant, restaurant [modern and luxurious tables, rooftop restaurants, Gym B. being new or newly renovated C. Cleanliness, aromas, cleanliness of the lobby and other areas of the hotel not being subjected to any pungent odors.

\subsubsection{Value}

Finally, value for the money was found to be a big contributing factor in customers' satisfaction. Value for the money is relatively high to the rating of the hotels. On the whole, customers of threestar hotels were satisfied with the most basic services that were available at these hotels. However, as expected, customers of five-star hotels had anticipated a high standard of service in relation to the amount of money they had to pay for the rooms and food. Hence, it is important for hotels to ensure that their guests leave the hotels with a good perception in terms of its value for the money. This will ensure that the same guests are willing to return in the future or make recommendations to others. .

\section{A. Room price B. Food and beverage price C. Free and complementary services (free shuttle bus)}

On the whole, the study has several implications. The comparison between attributes that contribute to customer satisfaction conducted by Zhou et al (2014) and other developing countries in Asia shows a great similarity between customers' expectations and comments. On this note, this study reveals that there was not much difference between the expectations and comments of customers of three-star hotels and 4 and 5 star hotels in Hangzhou. This finding can be utilised by hotel managers and others who work in related industries to improve the quality of service of their hotels. The hotel industry like any other business requires customers to buy their services and understanding their needs and expectations is the first step to improve performance.

As a hotel's success and growth is determined by its ability to understand and cater for the needs and expectations of the customers, it is crucial that studies such as this are conducted to elucidate important information on customers' perception on the hotel's performance. The study is particularly significant as it studied the expectations and satisfaction levels of actual users of the three, four and five-star hotels in Asia which were gleaned from the online reviews in a selected website which provided the researchers with a rich source of data.

On the whole, this study posits that travelers not only expect a comfortable place to stay with various amenities but also expect to be serviced by staff members who are warm and friendly and willing to cater to their requests. As such, it can be argued that employees who contribute to the guests' positive hotel experience contribute significantly towards customer satisfaction. In addition, the quality of the services that are provided to hotel guests is also significant in improving customer satisfaction,

This study has also illustrated that content analysis of online reviews of hotels by guests is a viable research tool. The methodology has provided a framework for an in-depth linguistic exploration of these comments to gain a clearer picture on the global expectations of the reviewers who were guests of the 3, 4 and 5-star hotels.

One limitation of this study is the unequal abilities of the reviewers to express themselves in English; not every reviewer is equally able to express their true perception and opinion in the language. However, the researchers were able to use the linguistic cues to overcome any semantic fuzziness that occurred as a result of linguistic flaws.

However, the researchers are optimistic that the specific findings will provide a rich source of information for hotel managements to improve on the quality of the various aspects of their hotels. Hotels are an important part in the effort to develop the tourism industry. This, in turn, has important implications on a country's economy. As tourism is an important source of income, satisfaction of customers with a hotel of their choice in tourist destinations is significantly important as it can affect a tourist's intention to return to the same destination in the future. This has been documented in past studies which had suggested that accommodation facilities affect tourist satisfaction with a destination (Pizam, Neumann \& Reichel, 1978). In addition, customers' satisfaction with a particular hotel chain 
can also influence their brand loyalty (Nam, Ekinci \& Whyatt, 2011). Hence, this study argues that it is crucial that those involved in the hospitality sector must be vigilant in ensuring customer satisfaction with the hotels that are available.

\section{REFERENCES}

[1] Agag, G., \& El-Masry, A. A. (2016). Understanding the determinants of hotel booking intentions and moderating role of habit. International Journal of Hospitality Management, 54, 52-67.

[2] Bulchand-Gidumal, J., Melián-González, S., \& Lopez-Valcarcel, B. G. (2013). A social media analysis of the contribution of destinations to client satisfaction with hotels. International Journal of Hospitality Management, 35, 44- 47.

[3] Callan, R. J., \& Bowman, L. (2000). Selecting a hotel and determining salient quality attributes: a preliminary study of mature british travelers. International Journal of tourism research 2(2), 97-118.

[4] Chan, E. S. W., \& Wong, S. C. K. (2006). Hotel selection: When price is not the issue. Journal of Vacation Marketing, 12, 142-159.

[5] Choi, T. Y., \& Chu, R. (2001). Determinants of hotel guests' satisfaction and repeat patronage in the Hong Kong hotel industry. Hospitality Management, 20, 277-297.

[6] Darini, M., \& Khozaei, F. (2016). The study of factors affecting customer's satisfaction with the three star hotels in Dubai International Journal of Advanced Engineering, Management and Science, 2(2), 21-24.

[7] Heung, V. C. S. (2000). Satisfaction levels of mainland Chinese travelers with Hong Kong hotel services. International Journal of Contemporary Hospitality Management, 12(5), 308-315.

[8] Huertas-Garcia, R., García, M. L., \& Consolación3, C. (2012). Conjoint Analysis of Tourist Choice of Hotel Attributes Presented in Travel Agent Brochures. International journal of tourism research 16 (1), 91-94.

[9] Jani, D., \& Han, H. (2014). Personality, satisfaction, image, ambience, and loyalty: Testing their relationships in the hotel industry. International Journal of Hospitality Management, 37, 11-20.

[10] Kattara, H. S., Weheba, D., \& El-Said, O. A. (2008). The Impact of Employee Behaviour on Customers' Service Quality Perceptions and Overall Satisfaction. Tourism and Hospitality Research, 8(4), 309-323.

[11] Kumar, S., \& Singh, D. (2014). Exploring Hotel Selection Motives among Indian Tourists. Indian Journal of Research in Management, Business and Social Sciences, 2(1), 82-87.

[12] Li, H., Ye, Q., \& Law, R. (2013). Determinants of Customer Satisfaction in the Hotel Industry: An Application of Online Review Analysis. International Journal of Hospitality Management, 18(7), 316-330.

[13] Lin, C.-N., Tsai, L.-F., Wang, P.-W., Su, W.-J., \& Shaw, J.-C. (2011). Using the Expected Importance and Perceived Satisfaction of Tourists to Construct Indicators for Improvement of Resort Hotel Service Quality. International Journal of Computer Science and Network Security, 11(4), 91-94.

[14] Nam, J., Ekinci, Y., \& Whyatt, G. (2011). Brand equity, brand loyalty and consumer satisfaction. Annals of Tourism Research, 38(3), 1009-1030.

[15] Pizam, A., Neumann, Y., \& Reichel, A. (1978). Dimensions of tourist satisfaction with a destination Annals of Tourism research 314-322.

[16] Ren, L., Qiu, H., Wang, P., \& Lin, P. M. C. (2016). Exploring customer experience with budget hotels: Dimensionality and satisfaction. International Journal of Hospitality Management, 52, 13-23.

[17] Rhee, H. T., \& Yang, S.-B. (2013). How does hotel attribute importance vary among different travelers? An exploratory case study based on a conjoint analysis. Electronic markets, 6(1), ??

[18] Shanahan, K. J., \& Hyman, M. R. (2006). An exploratory study of desired hotel attributes for American tourists vacationing in China and Ireland. Journal of Vacation Marketing, 13(2), 107118.

[19] Zhou, L., Ye, S., Pearce, P. L., \& Wu, M.-Y. (2014). Refreshing hotel satisfaction studies by reconfiguring customer review data. International Journal of Hospitality Management, 38, 1-10.

[20] Lee, W., Lin, J., Lee, S., Yeh, C,. \&Lee, F (2015) Customization Bridges the Gap Between Tourist Knowledge and Satisfaction Tourism Analysis 20(5), 475-485. 